\title{
ANXIOLYTIC AND ANTIDEPRESSANT EFFECTS OF MATRICARIA CHAMOMILLA HYDROALCOHOLIC EXTRACT IN A RAT MODEL OF SCOPOLAMINE
}

\author{
RADU IONIȚA $\breve{A}^{1}$, PAULA ALEXANDRA POSTU ${ }^{1}$, OANA CIOANC $\breve{~}^{2 *}$, CORNELIA MIRCEA $^{2}$, \\ MONICA HẲNCIANU ${ }^{2}$, LUCIAN HRIȚCU ${ }^{1}$ \\ ${ }^{1}$ Alexandru Ioan Cuza University, Department of Biology, 11 Bd. Carol I, Iaşi, România \\ ${ }^{2}$, , Gr. T. Popa" University of Medicine and Pharmacy Iaşi, Faculty of Pharmacy, Department of Pharmacognosy, \\ Universității 16, Iași, România
}

*corresponding author: oana.cioanca@gmail.com

Manuscript received: March 2018

\begin{abstract}
In the present study, we investigated the effects of the Matricaria chamomilla (chamomile) hydroalcoholic extract on anxiety and depression using a scopolamine rat model. Behavioural procedures for anxiety and depression were assessed in rats using elevated plus maze and forced swimming tests. The chamomile extract ( 25 and $75 \mathrm{mg} / \mathrm{kg} \mathrm{b.w}$.) was given intraperitoneally once daily for 21 days, and scopolamine $(0.7 \mathrm{mg} / \mathrm{kg}$ b.w.) was injected 30 minutes before the behavioural tests to induce anxiety and depression. The extract efficacy was matched by those elicited by diazepam $(1.5 \mathrm{mg} / \mathrm{kg}$ b.w.) and tramadol (10 $\mathrm{mg} / \mathrm{kg} \mathrm{b.w.)} \mathrm{for} \mathrm{anxiolytic} \mathrm{and} \mathrm{antidepressant} \mathrm{studies.} \mathrm{Our} \mathrm{results} \mathrm{demonstrated} \mathrm{that} \mathrm{the} \mathrm{extract} \mathrm{abolishes} \mathrm{scopolamine-}$ induced increasing of anxiety and depressive-like responses and exhibited therapeutic benefits for the management of psychological ailments.
\end{abstract}

\section{Rezumat}

În prezentul studiu, am investigat efectele extractului hidroalcoolic obținut din Matricaria chamomilla (mușețel) asupra comportamentului anxios și depresiv, utilizând un model animal indus cu scopolamină. S-au utilizat testele labirintului în cruce suspendat și înotului forțat pentru evaluarea comportamentului anxios și depresiv. Extractul de muşetel $(25 \mathrm{şi} 75 \mathrm{mg} / \mathrm{kg}$ corp) a fost administrat intraperitoneal o dată pe zi timp de 21 de zile, în timp ce scopolamina $(0,7 \mathrm{mg} / \mathrm{kg}$ corp) a fost injectată cu 30 de minute înainte de declanşarea testelor comportamentale pentru a induce anxietate şi depresie. Eficacitatea anxiolitică și antidepresivă a extractului a fost comparată cu cea exercitată de diazepam $(1,5 \mathrm{mg} / \mathrm{kg}$ corp $)$ și de tramadol (10 $\mathrm{mg} / \mathrm{kg}$ corp). Rezultatele experimentale indică faptul că extractul de mușețel manifestă efecte anxiolitice şi antidepresive, şi a prezentat beneficii terapeutice în gestionarea afecțiunilor psihice.

Keywords: Matricaria chamomilla extract, scopolamine, anxiety, depression.

\section{Introduction}

A strong association between Alzheimer's disease (AD) and depression was evidenced [15]. Moreover, increased dementia risk in depression has been reported [15]. There are a lot of mechanisms that may link depression with dementia such as vascular disease [1], increased cortisone levels [20], hippocampal atrophy associated with cognitive deficits [4], accumulating brain amyloid beta $(\mathrm{A} \beta)$ plaques [3], chronic brain inflammation [14], and finally decreased levels of circulating brain-derived neurotrophic factor (BDNF) [13].

Accumulating evidence suggested that scopolamine, an acetylcholine muscarinic receptor antagonist, had been used in experimental animals to induce amnesia, mimicking a type of dementia observed in AD [7]. As compared to humans, rats given scopolamine exhibited a high level of anxiogenic response in specific behavioural tests such as the open field and light/dark test [10]. The authors attributed this effect to scopolamine in rats mainly due to the disruption of the hippocampal cholinergic function resulting in alteration of contextual processing [21].

Chamomile is a well-known medicinal plant from the Asteraceae family used for therapeutical purposes [6]. Recent data indicated that chamomile extract is used in treatment for generalized anxiety disorder [16] and also provides antidepressant activity in anxious and depressed humans [2]. Additionally, antioxidative and cytotoxic effects of chamomile against cancer cells have been reported [18]. Therefore, in the present study, we investigated the potential anxiolytic and antidepressant effects of chamomile extract in the scopolamine-induced model [12].

\section{Materials and Methods}

Plant material and extraction procedure. Dry flowers of Matricaria chamomilla were purchased from the Romanian pharmaceutical market in 2016 and identified in the Department of Pharmacognosy, "Gr T. Popa" University of 
FARMACIA, 2019, Vol. 67, 1

Medicine and Pharmacy Iaşi, Romania where a voucher specimen (No. C1-072016) was deposited. $2.5 \mathrm{~g}$ of the dry inflorescence was extracted with $100 \mathrm{~mL}$ of $50 \%$ ethanol and refluxed $30 \mathrm{~min}$ in a water bath. The extract was filtered and concentrated by oven drying at $40^{\circ} \mathrm{C}$, weighed $(\mathrm{m}=1.3 \mathrm{~g})$ and stored at $4^{\circ} \mathrm{C}$, and used to treat the animals as needed [8]. The extract was resuspended in sterile saline for further analyses.

HPLC/DAD analysis. A Thermo UltiMate3000 HPLC system equipped with quaternary pumps controlled by Chromeleon interface, an autosampler and multidiode array detector (DAD) were used for the HPLC analyses. Solvents were filtered using a Millipore system and analysis was performed on an Accucore XL C18 column (150 x 4.6 mm, $4 \mu \mathrm{m})$. The used mobile phase was acetonitrile (A) and water containing $0.1 \%$ acetic acid (B) and the composition gradient was: $10 \%-23 \%$ (A) in $5 \mathrm{~min}$; $23 \%$ (A) isocratic for $10 \mathrm{~min}$ and then $23 \%-35 \%$ (A) in $12 \mathrm{~min} ; 35 \%-70 \%$ (A) for $5 \mathrm{~min}$. The injection volume was $20 \mu \mathrm{L}$, scanning absorbance wavelengths from $240 \mathrm{~nm}$ to $520 \mathrm{~nm}$, typical for phenols. Each solution was injected in triplicate, and the calibration curves were constructed with the averages. The main compounds identified in the Matricaria chamomilla extract were: chlorogenic acid, cafeic acid, catechin, apigenin-7-glucoside, rutin -, cynaroside, luteolin and apigenin.

Animals. 30 male Wistar rats (4 month-old) weighing $250 \pm 10 \mathrm{~g}$ at the start of the experiment were used. The animals were housed in a temperature and light-controlled room $\left(22^{\circ} \mathrm{C}\right.$, a 12 $\mathrm{h}$ cycle starting at $08: 00 \mathrm{~h})$ and were fed and allowed to drink water ad libitum. The rats were divided into 6 groups (5 animals per group): (1) control group received saline treatment $(0.9 \%$ $\mathrm{NaCl}$ ); (2) scopolamine (Sco)-alone-treated group; (3) scopolamine (Sco, $0.7 \mathrm{mg} / \mathrm{kg}$ b.w., i.p.)-treated group received chamomile extract treatment (25 $\mathrm{mg} / \mathrm{kg}$ ) (Sco+MC (25 kg/kg,b.w., i.p.)) and (4) scopolamine (Sco)-treated group received chamomile extract treatment $(75 \mathrm{mg} / \mathrm{kg}$ b.w., i.p.) $(\mathrm{Sco}+\mathrm{MC}(75 \mathrm{~kg} / \mathrm{kg}$ b.w., i.p.)). Also, there are more two groups as referred to (5) diazepam group (DIAZ) [19] and (6) tramadol group (TRM) [17] used as positive controls within the elevated plus maze and forced swimming tests. Rats were treated by the guidelines of animal bioethics from the Act on Animal Experimentation and Animal Health and Welfare from Romania, and all procedures were in compliance with Directive 2010/63/EU of the European Parliament and of the Council of 22 September 2010 on the protection of animals used for scientific purposes. This study was approved by the Committee on the Ethics of Animal Experiments of the Alexandru Ioan Cuza University of Iaşi (permit number: 2200), and also, efforts were made to minimize animal suffering and to reduce the number of animals used.
Elevated plus-maze (EPM). This test is part of the behavioral tests that study anxiety as a component of cognitive processes. The device was made of gray Plexiglas and consists of four arms, $49 \mathrm{~cm}$ long and $10 \mathrm{~cm}$ wide, elevated $50 \mathrm{~cm}$ above the ground. Two arms were enclosed by walls $30 \mathrm{~cm}$ high, and the other two arms are open. Light levels on the open and enclosed arms were similar. A video camera was mounted on the ceiling above the apparatus, and the experiments were taped for later behavioural evaluation. At the beginning of the experiment, the rat was placed in the center of the maze, and the following variables were scored: (1) the time spent in the open arms and the enclosed arms; (2) the number of entries to any of the four arms. An arm entry was defined as the entry of all four feet of the animal into one arm. The test lasted $5 \mathrm{~min}$, and the apparatus was thoroughly cleaned after removal of the rat with cotton and $10 \%$ ethanol solution [11]. In this test, diazepam, an anxiolytic agent, was used as reference drug.

The forced swimming test (FST). The most commonly used animal model for depression is the forced swimming test (FST). The theoretical reasoning of the model is that of exposure to uncontrolled stress resulting in behaviours that stimulate anhedonia, a typical syndrome of human depression. In the FST, rats were introduced into transparent cylindrical plastic tanks (height $=59$ $\mathrm{cm}$, internal diameter $=30 \mathrm{~cm}$ ) containing water to a level of $25 \mathrm{~cm}\left(26 \pm 1{ }^{\circ} \mathrm{C}\right)$. Water was always changed for each rat. Rats are exposed to a 15-min pretest swim period and followed the next day with a 6-min test swimming session. Both swimming sessions were conducted between 12.00-18.00 h. After each swimming session, the rats were removed from water, dried with towels and placed in a warm enclosure for $20 \mathrm{~min}$ and then returned to their initial cages. During the single exposure to forced swimming ( $6 \mathrm{~min})$, the behaviour of the rat was recorded on videotape. The following two types of behaviour were distinguished and measured with a stopwatch by one experimenter: (1) immobility (while the animal is immobile and floats in a straight position and only makes minimal movements to keep the head on the surface of the water); and (2) swimming (time spent with active swimming movements) [11]. In this test, tramadol, an antidepressant and analgesic agent, was used as reference drug.

Drug administration. Chamomile extract was intraperitoneally (i.p.) administrated (25 and $75 \mathrm{mg} / \mathrm{kg}$ b.w., i.p.), once daily, for 21 consecutive days (18 days before and 3 days during EPM and FST), and also with $30 \mathrm{~min}$ before the behavioural tests. Sco $(0.7 \mathrm{mg} / \mathrm{kg}$ b.w., i.p.) was administrated individually or in combination with chamomile extract, $30 \mathrm{~min}$ before the behavioural tests (EPM and FST). DIAZ (1.5mg/kg b.w.) and TRM $(10 \mathrm{mg} / \mathrm{kg}$ b.w.) were i.p. administered $30 \mathrm{~min}$ 
before the behavioral tests (EPM and FST). Control animals received i.p. an equal volume of sterile saline ( $1 \mathrm{~mL} / \mathrm{kg}$ b.w).

Statistical analysis. The animal's behavioural activities in the elevated plus maze and the forced swimming test tasks were statistically analysed by one-way analysis of variance (ANOVA) using GraphPad Prism version 7.00 for Windows, GraphPad Software, La Jolla California USA following by Tukey's post hoc test. All results are expressed as mean \pm standard errors of the mean (S.E.M). $p<0.05$ was regarded as statistically significant.

\section{Results and Discussion}

Anxiety assessement in the elevated plus maze task. Scopolamine injection significantly decreased the percentage of the time spent in the open arm $(p<0.01)$ compared to the control group. In contrast, administration of the chamomile extract significantly reversed the decreased open arm time percentage $(p<0.0003$ for $25 \mathrm{mg} / \mathrm{kg} \quad$ b.w. and $\mathrm{p}<0.0001$ for $75 \mathrm{mg} / \mathrm{kg}$ b.w.) (Figure 1a). The number of entries in the open arms was significantly increased by scopolamine $(p<0.01)$ compared to the control group, while administration of the chamomile extract significantly increased the entries in the open arms $(\mathrm{p}<0.0001$ for $75 \mathrm{mg} / \mathrm{kg}$ b.w.) (Figure 1b). As can be seen in figure 1c, the injection of scopolamine significantly affected locomotor activity as assessed by the number of crossings $(p<0.01)$ compared to the control group. Treatment with the chamomile extract significantly increased the locomotor activity $(p<0.001$ for $25 \mathrm{mg} / \mathrm{kg}$ b.w. and $\mathrm{p}<0.0001$ for $75 \mathrm{mg} / \mathrm{kg}$ b.w.), suggesting anxiolytic profile. Our results are in line with those of Can et al. [5] considering the psychopharmacological profile of chamomile (Matricaria recutita L.) essential oil in mice. The authors concluded that the chamomile extract exhibited a psychostimulant effect similar to caffeine and increased parameters in the elevated plus maze test. Our results demonstrated that the chamomile extract removed the anxiogenic effects of scopolamine, acting as an anxiolytic agent with the values close by related to diazepam.

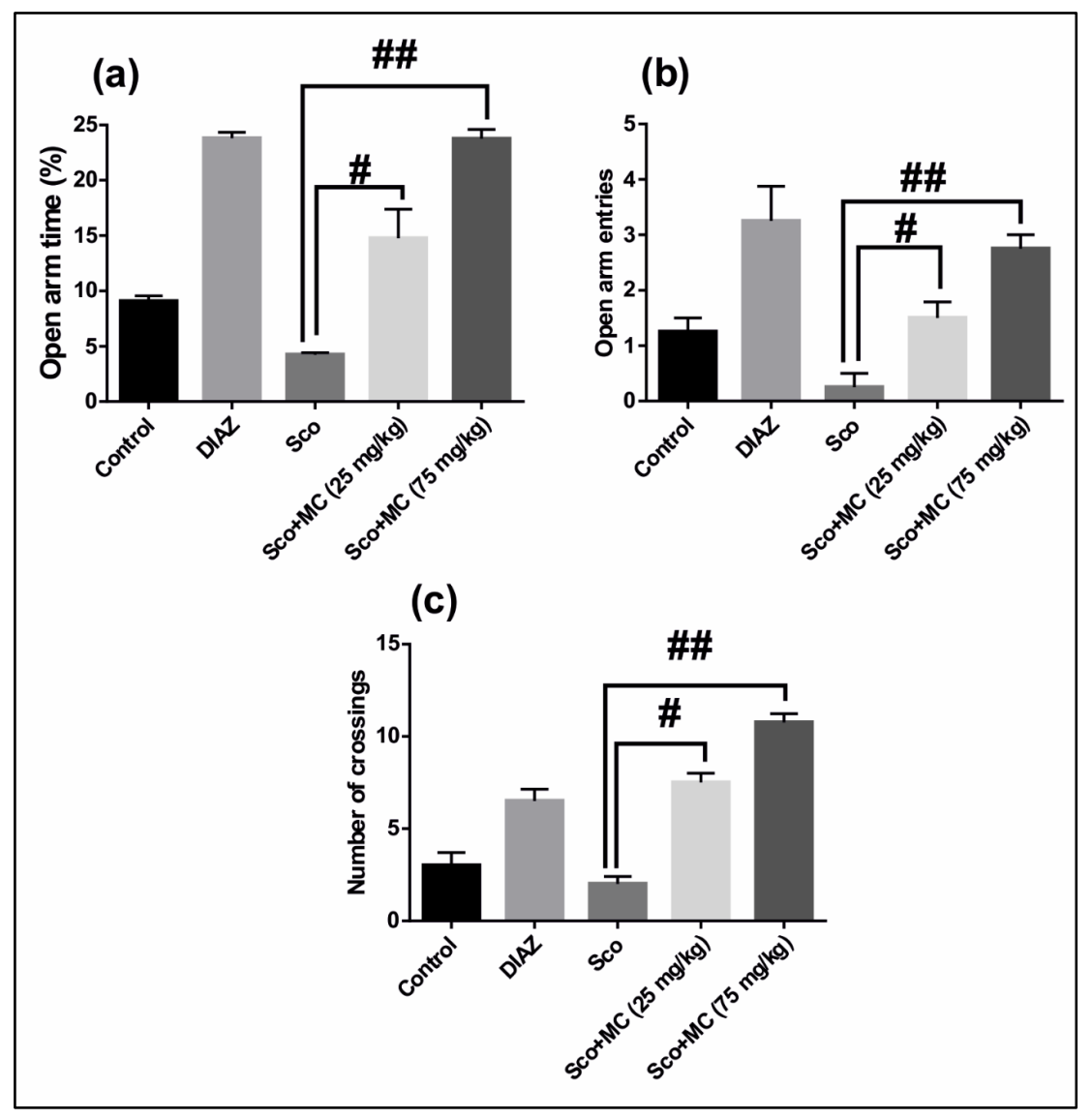

Figure 1

Effects of the Matricaria chamomilla (MC) hydroalcoholic extract ( 25 and $75 \mathrm{mg} / \mathrm{kg} \mathrm{b.w.)} \mathrm{in} \mathrm{the} \mathrm{elevated} \mathrm{plus-maze} \mathrm{test} \mathrm{on}$ the percentage of the time spent in the open arms (a), on the number of open-arm entries (b) and on the number of crossing (c) in the scopolamine (Sco, $0.7 \mathrm{mg} / \mathrm{kg}$ b.w.)-treated rats. Values are means \pm S.E.M. ( $\mathrm{n}=6$ animals per group). For Tuckey's post hoc analyses: ${ }^{\#} \mathrm{Sco} v s$. Sco+MC (25mg/kg b.w.): p $<0.0003$ and ${ }^{\# \#} \mathrm{Sco} v s$. Sco+MC (75mg/kg b.w.): p $<0.0001$ (a), ${ }^{\#} \mathrm{Sco}$ vs. Sco+MC (25mg/kg b.w.): $\mathrm{p}<0.01$ and ${ }^{\#} \mathrm{Sco} v$. Sco $+\mathrm{MC}\left(75 \mathrm{mg} / \mathrm{kg}\right.$ b.w.): $\mathrm{p}<0.001$ (b) and ${ }^{\#} \mathrm{Sco} v$. Sco $+\mathrm{MC}(25 \mathrm{mg} / \mathrm{kg}$ b.w.): $<<0.001$ and ${ }^{\#}$ Sco vs. Sco + MC $(75 \mathrm{mg} / \mathrm{kg}$ b.w.): $<<0.0001$ (c). Diazepam group (DIAZ) was used as positive control. 
Depression assessment in the forced swimming test. The figures $2 \mathrm{a}$ and $2 \mathrm{~b}$ respectively indicated the behaviours of rats subjected to FST. Scopolamineinduced a depressive-like response as evidenced by a significant decrease of the swimming time $(\mathrm{p}<0.0001)$ (Fig. 2a) and a significant increase of the immobility time $(\mathrm{p}<0.0001)$ (Fig. 2b) as compared to the control groups. Administration of the chamomile extract removed the scopolamineinduced depression in rats. Gordinho Pinto et al. [9] analysing the forced swimming test data, demonstrated that the treatment with chamomile $6 \mathrm{cH}$ produced a recovery of scopolamine-induced depression in rats to an intermediate state between the baseline control (non-stressed mice) and amitriptyline treated animals.

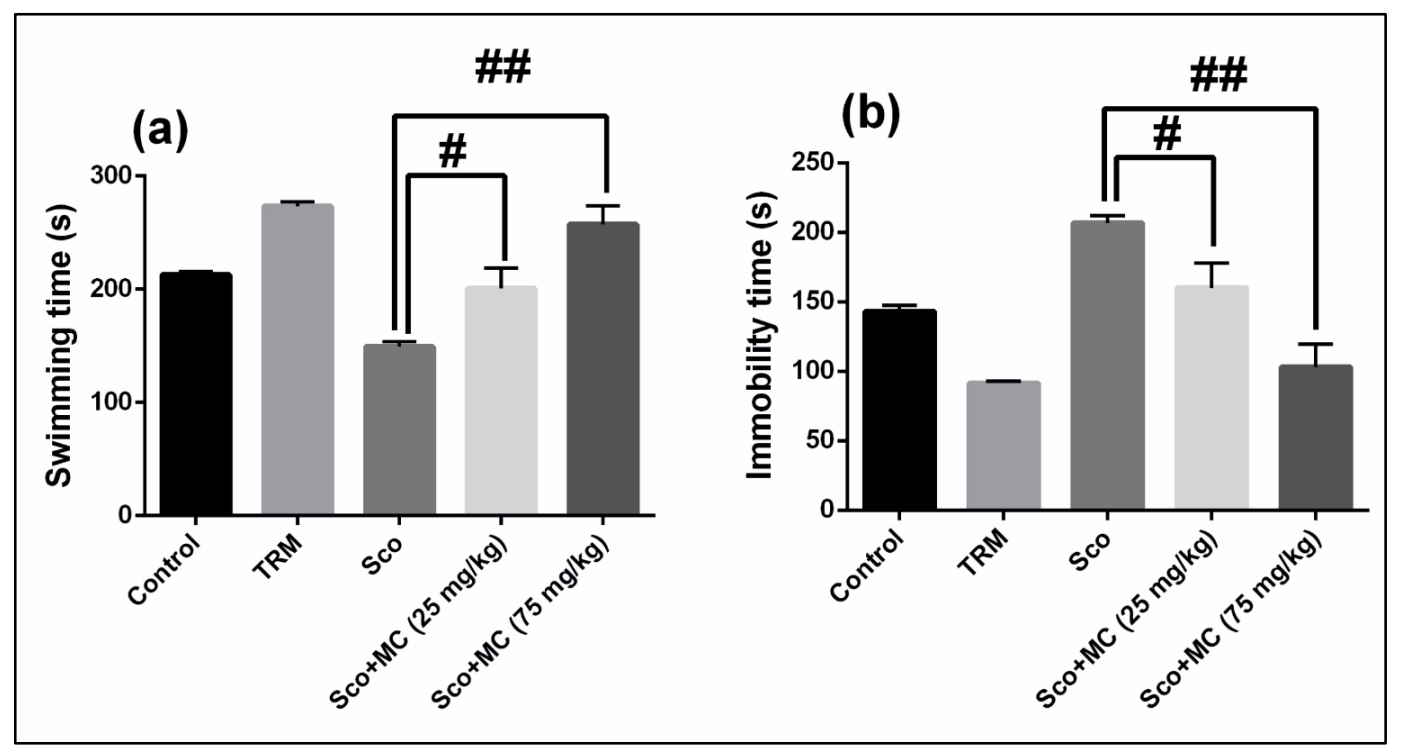

Figure 2

Effects of the Matricaria chamomilla (MC) hydroalcoholic extract ( 25 and $75 \mathrm{mg} / \mathrm{kg} \mathrm{b.w.)} \mathrm{on} \mathrm{swimming} \mathrm{time} \mathrm{(a)} \mathrm{and}$ immobility time (b) in the scopolamine (Sco, $0.7 \mathrm{mg} / \mathrm{kg}$ b.w.)-treated rats during the $6 \mathrm{~min}$ period in the forced swimming test. Values are means \pm S.E.M. ( $\mathrm{n}=6$ animals per group). For Turkey's post hoc analyses - ${ }^{\#} \mathrm{Sco} v \mathrm{~s}$. Sco $+\mathrm{MC}(25 \mathrm{mg} / \mathrm{kg}$ b.w.): $\mathrm{p}<0.0001$ and ${ }^{\# \#}$ Sco vs. Sco+MC (75mg/kg b.w.): $<<0.0001$ (a) and ${ }^{\#}$ Sco vs. Sco+MC (25mg/kg b.w.): $<<0.0001$ and ${ }^{\#}$ Sco vs. Sco+MC (75mg/kg b.w.): $\mathrm{p}<0.0001$ (b). Tramadol group (TRM) was used as positive control.

\section{Conclusions}

In this study, the results obtained suggest that the treatment with the chamomile extract acts as anxiolytic and antidepressant agents in the scopolamine rat model and that anxiolyticantidepressant-like effects are related to the cholinergic system.

\section{References}

1. Alexopoulos GS, Meyers BS, Young RC, Campbell $\mathrm{S}$, Silbersweig D, Charlson M, "Vascular depression" hypothesis. Arch Gen Psychiatry, 1997; 54(10): 915-922.

2. Amsterdam JD, Shults J, Soeller I, Mao JJ, Rockwell K, Newberg AB, Chamomile (Matricaria recutita) may have antidepressant activity in anxious depressed humans - An exploratory study. Altern Ther Health Med., 2012; 18(5): 44-49.

3. Blennow K, de Leon MJ, Zetterberg H, Alzheimer's disease. The Lancet, 2006; 368(9533): 387-403.

4. Butters MA, Young JB, Lopez O, Aizenstein HJ, Mulsant BH, Reynolds CF, DeKosky ST, Becker JT, Pathways linking late-life depression to persistent cognitive impairment and dementia. Dialogues Clin Neurosci., 2008; 10(3): 345-357.

5. Can ÖD, Demir Özkay Ü, Kıyan HT, Demirci B, Psychopharmacological profile of Chamomile
(Matricaria recutita L.) essential oil in mice. Phytomedicine, 2012; 19(3): 306-310.

6. Cioanca O, Mircea C, Poiata A, Stanescu U, Hancianu M, Contributions to the study of the pharmaceutical quality of some chamomile comercial samples. Note II. The microbial contamination. Farmacia, 2011; 59: 784-793.

7. Deiana S, Harrington CR, Wischik CM, Riedel G, Methylthioninium chloride reverses cognitive deficits induced by scopolamine: comparison with rivastigmine. Psychopharmacology, 2008; 202(1): 53.

8. Gacea $\mathrm{O}, \mathrm{PhD}$ thesis: Reserch about the pharmaceutical quality of Chamomillae flos. $U M F$, Gr.T.Popa, Iași, 2010 (available in Romanian).

9. Gordinho Pinto SA, Bohland E, de Paula Coelho C, Furquim de Azevedo Morgulis MS, Bonamin LV, An animal model for the study of Chamomilla in stress and depression: pilot study. Homeopathy, 2008; 97(3): 141-144.

10. Hughes RN, Otto MT, Anxiolytic effects of environmental enrichment attenuate sex-related anxiogenic effects of scopolamine in rats. Prog Neuro-Psychopharmacol Biol Psychiatry, 2013; 40: 252-259.

11. Ionita R, Valu VM, Postu PA, Cioanca O, Hritcu L, Mihasan M, 6-hydroxy-1-nicotine effects on anxiety 
and depression in a rat model of chlorisondamine. Farmacia, 2017; 65(2): 237-240.

12. Klinkenberg I, Blokland A, The validity of scopolamine as a pharmacological model for cognitive impairment: A review of animal behavioral studies. Neuroscience \& Biobehavioral Reviews, 2010; 34(8): 1307-1350.

13. Krishnan V, Nestler EJ, The molecular neurobiology of depression. Nature, 2008; 455(7215): 894-902.

14. Leonard BE, Inflammation, depression and dementia: Are they connected? Neurochem Res, 2007; 32(10): 1749-1756.

15. Leyhe T, Reynolds CF, Melcher T, Linnemann C, Klöppel S, Blennow K, Zetterberg H, Dubois B, Lista S, Hampel H, A common challenge in older adults: Classification, overlap, and therapy of depression and dementia. Alzheimers Dement, 2017; 13(1): 59-71.

16. Mao JJ, Xie SX, Keefe JR, Soeller I, Li QS, Amsterdam JD, Long-term chamomile (Matricaria chamomilla L.) treatment for generalized anxiety disorder: A randomized clinical trial. Phytomedicine, 2016; 23(14): 1735-1742.

17. Ostadhadi S, Norouzi-Javidan A, Chamanara M, Akbarian R, Imran-Khan M, Ghasemi M, Dehpour
AR, Involvement of NMDA receptors in the antidepressant-like effect of tramadol in the mouse forced swimming test. Brain Research Bulletin, 2017; 134: 136-141.

18. Park EH, Bae WY, Eom SJ, Kim KT, Paik HD, Improved antioxidative and cytotoxic activities of chamomile (Matricaria chamomilla) florets fermented by Lactobacillus plantarum KCCM 11613P. J Zhejiang Univ Sci B, 2017; 18(2): 152160.

19. Rincón-Cortés M, Gagnon KG, Dollish HK, Grace AA, Diazepam reverses increased anxiety-like behavior, social behavior deficit, and dopamine dysregulation following withdrawal from acute amphetamine. Neuropsychopharmacology, 2018; 43(12): 2418-2425.

20. Wolkowitz OM, Epel ES, Reus VI, Mellon SH, Depression gets old fast: do stress and depression accelerate cell aging? Depress Anxiety, 2010; 27(4): 327-338.

21. Zelikowsky M, Hast TA, Bennett RZ, Merjanian M, Nocera NA, Ponnusamy R, Fanselow MS, Cholinergic blockade frees fear extinction from its contextual dependency. Biol Psychiatry, 2013; 73(4): 345-352. 